\title{
Renal Outcomes and Myocardial Performance after On-Pump Beating Heart versus Conventional On-Pump Surgery in Patients with Preoperative Low Glomerular Filtration Rate
}

\section{Salih Colak¹, Davut Azboy², Zeki Temizturk², Hakan Atalay³, Omer Faruk Dogan4, Dilek Dogan5, Emjed Khalil2, Kenan Abdurrahman Kara6}

\footnotetext{
${ }^{1}$ Department of Cardiology, The Health and Science University, Adana Numune Education and Training Hospital, Adana, Turkey ${ }^{2}$ Department of Cardiovascular Surgery, The Health and Science University, Elazig Education and Training Hospital, Elazığ, Turkey ${ }^{3}$ Department of Cardiovascular Surgery, Mersin Private Middle-East Hospital, Mersin, Turkey

${ }^{4}$ Department of Cardiovascular Surgery, The Health and Science University, Adana Numune Education and Training Hospital, Adana, Turkey ${ }^{5}$ Department of Dietetic and Parenteral Nutrition, The Health and Science University, Adana Numune Education and Training Hospital, Adana, Turkey ${ }^{6}$ Department of Cardiovascular Surgery, The Private Medicana Çamlıca Hospital, Istanbul, Turkey

Email: ofdogan@hacettepe.edu.tr
}

How to cite this paper: Colak, S., Azboy, D., Temizturk, Z., Atalay, H., Dogan, O.F., Dogan, D., Khalil, E. and Kara, K.A. (2016) Renal Outcomes and Myocardial Performance after On-Pump Beating Heart versus Conventional On-Pump Surgery in Patients with Preoperative Low Glomerular Filtration Rate. World Journal of Cardiovascular Diseases, 6, 433-445.

http://dx.doi.org/10.4236/wjcd.2016.611047

Received: July 12, 2016

Accepted: November 27, 2016

Published: November 30, 2016

Copyright $\odot 2016$ by authors and Scientific Research Publishing Inc. This work is licensed under the Creative Commons Attribution International License (CC BY 4.0).

http://creativecommons.org/licenses/by/4.0/ (c) (i) Open Access

\section{Abstract}

Objective: Acute kidney disease develops $16 \%$ - 30\% of patients with preoperative impaired renal functions. Our aim of this study was to compare postoperative renal outcomes using two open heart surgery techniques, on-pump beating heart $(\mathrm{OPBH})$ and conventional on-pump (COP), in patients who have preoperative low glomerular filtration rate (eGFR) as an indicator of creatinine clearance. Methods: From 2004 to 2015,341 patients with preoperative creatinine clearance were lower than 90 $\mathrm{ml} / \mathrm{min} / 1.73 \mathrm{~m}^{2}$ were selected for this study. On-Pump beating heart was performed in 111 patients (Group I). Conventional on-pump technique was used in 200 patients. In the remaining patients, we measured postoperative Tumor Necrosis Factor Alpha (TNF-alpha), cardiac troponin I (cTn-I), Brain natriuretic peptid (NT-Pro$\mathrm{BNP})$, creatinine (Cr), blood urea nitrogen (BUN) and postoperative eGFR daily until day four after surgery. Results: There were no differences in baseline levels of TNF-alpha, NT-Pro-BNP, BUN, cTn-I, Cr levels between the groups. Cardiopulmonary bypass (CPB) time were much longer and cumulative inotrope use was significantly higher in patients underwent COP $(\mathrm{P}<0.05)$. Postoperative TNF-alpha and c-TnI was significantly higher in group II $(\mathrm{P}<0.001)$. In group II, blood urea nitro- 
gen and creatinine levels were high significantly $(\mathrm{P}<0.001)$. Three patients in Group I (2.7\%), and 6 patients (6.2\%) in Group II required hemodialyses after surgery. Data revealed all-cause survivals at 1 and 24 months of $88 \%$ and $75 \%$ for OPBH versus $78 \%$ and $59 \%$ for COP technique $(\mathrm{P}=0.021 ; \mathrm{P}=0.034)$. In a comorbidity adjusted Cox model, OPBH was associated with a $22 \%$ reduction in all-cause morbidity $(\mathrm{P}=$ 0.03). Conclusion: Our study showed that on-pump beating heart CABG technique provides a morbidity benefit and is associated with a lower risk of peroperative LOS in patients with mild renal disfunction. Our study results suggest that OPBH is superior to the $\mathrm{COP}$ in terms of postoperative renal injury and cardiac mediators.

\section{Keywords}

Open Heart Surgery, Beating Heart, Postoperative Renal Failure

\section{Introduction}

In recent years, the on-pump beating heart coronary artery bypass grafting as an alternative technique has gained acceptance to provide harmful effects of classical CABG operations includes cross-clamping, cardioplegia and unloading the heart. This technical approach preserves both native coronary blood flow and cardiac output during surgery. A metaanalysis revealed that the better short-term outcomes and late survival rates following on-pump beating heart technique compared with conventional CABG. However, a limited number of previous studies comparing the outcomes of $\mathrm{ONBH}$ and classical CABG techniques in a similar patient population. Therefore, we decided to compare the short-term outcomes after two different techniques in a matched population. The incidence of acute kidney disease (AKD) in the early postoperative period was $0.6 \%-5 \%$ in patients with normal preoperative renal function who had been subjected to cardiac surgery [1] [2] [3] [4]. Approximately $0.6 \%$ to $5 \%$ of those patients are required hemodialysis in the postoperative period [2] [3]. Age, aortic cross-clamp time, preoperative vasopressor use, visceral hypoperfusion, loss of pulsatile perfusion increases the peroperative AKD after cardiac surgery [1] [2] [3]. These patients have a very high early mortality rate of $25 \%$ compared with $1.5 \%$ to $2.2 \%$ in patients who do not require postoperative dialysis [2] [3].

As ECC has pathophysiologic sequels, there has been a revival of interest in performing $\mathrm{CABG}$ on a beating heart off-pump method. To avoid subsequent myocardial ischemia-reperfusion injury due to ECC, off-pump CABG technique has been proposed to reduce postoperative complications, one of which is renal insufficiency [3]. However, it has been shown that there was no any clinical evidence for renal improvement after off-pump procedures in CABG patients. Previous comparative showed that a preoperative renal function was the main risk factor of AKD development after open heart surgery [5]. Also, the authors also showed that a higher circulating TNF-alpha Receptor-1 independently predicts the progression to a worse GFR and AKD in individuals.

Therefore, to investigate the relationships between plasma TNF-alpha, cTN-I and N- 
Terminal Pro-brain Natriuretic Peptide (NT-BNP) levels and postoperative renal outcome, we compared two CABG techniques in CABG patients with mild renal impairement.

\section{Patients and Methods}

From January 2004 through June 2014, 2856 patients underwent isolated CABG or CABG and concomitant mitral valve surgery. Ethical committee of local hospital (Medicalpark University School of Medicine) approved this study. The informed consents were signed by the patients. The demographycs of the patients have been summarised in Table 1. At the discretion of the operating surgeon, myocardial revascularization (alone or concomitant mitral valve surgery) was performed on-pump beating heart in 378 patients. In the remaining patients, CABG was performed using an aortic cross clamping. Hospital outcomes and biochemical markers were compared after propensity-matched pairs of 111 OPBH (Group 1) and 96 COP (Group 2) patients. Two groups were similar in age, left ventricular ejection fraction (LVEF), extent of coronary artery disease (CAD), carotid artery disease, and chronic obstructive pulmonary disease. Both groups were also similar preoperative New York Heart Association (NYHA) class and EuroScore $(\mathrm{P}>0.05)$. The mean level of preoperative creatinine level was $1.7 \pm 0.6$ and $1.8 \pm 0.8 \mathrm{mgr} / \mathrm{dL}$ in Group I and II, respectively ( $\mathrm{P}>0.05$ ). In all patients, eGFR was calculated using an automated mathematic formula. e-GFR values were measured as 57 \pm 5.0 in Group 1 and as $54 \pm 4.4 \mathrm{~mL} / \mathrm{min}$. in Group 2. Exclusion criteria were: older age ( $>75$ years), emergent surgery, active infection, hepatic failure, the mean pulmonary artery pressure $\geq 35 \mathrm{mmHg}$, ejection fraction $\leq 45 \%$, congestive heart failure, thyroid disorders, stroke history, and preoperative supraventricular arrhytmia.

eGFR was calculated from the simplified Modification of Diet in Renal Disease study equation. AKD was classified according to the Risk, Injury, Failure, Loss of kidney function, and End-stage kidney disease (RIFLE) classification. In both groups, the patients have preoperative stage I kidney disease (Creatinine level $\geq 1.5 \mathrm{mg} / \mathrm{dL}$ or $50 \%$ increase after surgery). According to the postoperative creatinine levels, the patients have been classified in stage 1, 2 and 3 AKD in both groups.

Table 1. Basic variables of the groups.

\begin{tabular}{cccc}
\hline Variables & Group I $(\mathrm{n}=111)$ & Group II $(\mathrm{n}=99)$ & $\mathrm{P}$ \\
\hline Age (year) & $71.0 \pm 4.4$ & $69 \pm 5.4$ & 0.140 \\
BUN & $19.4 \pm 2.1$ & $21.2 \pm 1.5$ & 0.149 \\
Creatinine & $1.7 \pm 0.6$ & $1.8 \pm 0.8$ & 0.452 \\
Hemoglobin & $13.7 \pm 2.1$ & $14.6 \pm 1.3$ & 0.370 \\
Sodium & $144.0 \pm 7.4$ & $141.0 \pm 4.2$ & 0.440 \\
Fluid balance (intra-operative) & $1855.0 \pm 405.0$ & $1890.0 \pm 317.0$ & 0.115 \\
Potassium & $4.2 \pm 1.0$ & $4.1 \pm 1.0$ & 0.092 \\
GFR (ml/min) & $57.0 \pm 5.0$ & $54.0 \pm 4.4$ & 0.084 \\
\hline
\end{tabular}

Data are presented as mean \pm SD; One-way ANOVA test was used for data analysis; SD: Standard deviation; BUN: Blood urea nitrogen; GFR: Glomerular filtration rate. 
The urine out-put has been recorded for each patient during $48 \mathrm{hrs}$ in both groups. Blood creatinine and BUN level, arterial blood gas analyses, hemoglobine, sodium and potassium levels were measured. The measurements of Cr, BUN, cTn-I, TNF-alpha, and NT-Pro-BNP were recorded daily during hospital stay within postoperative four days. In both groups, all patients did receive furosemide after surgery. Risk, Injury, Failure, Loss of kidney function, and End-stage kidney disease (RIFLE) criteria which is focuses mainly on eGFR, has been used for staging of patients with kidney injuries. Fluid balance has been provided according to the consultant nephrologist. Blood samples were given from venous line for cTn-I, NT-ProBNP, and TNF-alpha release in both groups. Preoperative cTN-I, NT-ProBNP, and TNF-alpha were recorded in both groups (T0). The first blood samples were collected at the end of first day in the ICU (T1). The second blood samples were collected in the postoperative second day (T2). After then, postoperative blood samples for measuring were given postoperative 3 (T3) and 4 day (T4).

\subsection{Surgical Technique}

All operations were performed through a midline sternotomy. Internal thoracic artery and saphenous vein were harvested and prepared. Standard aortic and single venous cannulation was performed. There were no differences in ECC routine among the staff surgeons. Arterial flow was adjusted to 2.0 to $2.2 \mathrm{~L} / \mathrm{min} / \mathrm{m}^{-2}$, and blood pressure was maintained between 60 - $70 \mathrm{mmHg}$.

In Group I, operations were performed during on-pump beating heart method using an octopus and intracoronary shunt. Proxymal venous anastomosis were constructed first using a side clamp prior to starting of ECC. After then, CPB was instituted. Firstly, the left internal thoracic artery (LITA) was anastomosed to the left anterior descending artery. After then, distal anastomosis were constructed. In 26 CABG patients (23.4\%), the mitral valve surgery (replacement or plasty) has been done during beating heart via left atrial approach. If the patients required inotropic(s), dopamine and/or noradrenaline was administered at a dose of $7.5-10 \mu \mathrm{gr} / \mathrm{kg} / \mathrm{min}$. and $0.01 \mu \mathrm{gr} / \mathrm{kg} / \mathrm{min}$. The patients weaned from ECC, and were decannulated. Heparin was reversed using protamine. Aspirin or clopidogrel, as antiaggregants, was administered $24 \mathrm{hrs}$ postoperatively.

In Group II, to provide cardiac arrest an antegrade and retrograde cold blood cardioplegia was administered after an aortic clamping. Retrograde cardioplegia was given every 15 - 20 min. during the operation. Patients' temperatures were either kept warm or allowed to drift to $34^{\circ} \mathrm{C}$ during $\mathrm{CPB}$. Distal venous anastomoses were constructed first, after than LITA anastomosis was performed for LAD artery. Mitral valve surgery, replacement or plasty has been done via left atrial approach for 22 patients (22.9\%). The proximal anastomoses were completed using a side-clamp. If the patients required inotrop(s), dopamine and/or noradrenaline was administered prior to weaning from $\mathrm{CPB}$. Heparin was reversed, and aspirin or clopidogrel was administered $24 \mathrm{hrs}$ postoperatively. 


\subsection{Statistical Analyses}

Data were analysed using automated SPSS software version 17.0 (SPSS, Chicago, IL). Continuous variables were expressed as mean \pm SD. The distribution of continuous variables was evaluated using the Kolmogorov-Smirnov test. Independent groups with normal distribution were compared with independent sample t-tests. The MannWhitney $U$ test was used to determine the difference of variables in groups with non-normal distributions. Nominal data were compared with chi-square tests. The meanings of increments in the repeated measurements were evaluated with "General Linear Model-Repeated Measures". Paired sample t-test was employed for the comparison of the preoperative and postoperative variables in each group. $\mathrm{P}<0.05$ was considered statistically significant.

\section{Results}

To reduce the influence of selection on the comparison of outcome, we used propensity-score pairwise matching of two groups to the pool of available. This was a 2-step process. First, using known preoperative variables, and multivariable logistic regression, we determined the factors associated with $\mathrm{OPBH}$ versus COP. We initially analyzed the continuous and ordinal variables by means of decile analysis, selecting those transformations of scale that best calibrated the variable to group membership.

Sex, body mass index, left ventricular function, smoking history, chronic obstructive pulmonary disease, and left main disease were similar in both groups. In-hospital outcomes, mortality and morbidity, were recorded. Postoperative complications occurring in the ICU and by experienced doctors also dedicated to collecting patient information, operative details, and in-hospital complications. Operative variables compared included bypass conduits, number and site of distal anastomoses. Revascularization was completed in all patients. Postoperative events identified according to definitions of the Adult Cardiac Surgery Database included hospital death, stroke, myocardial infarction, reoperation for bleeding, red blood cell use, sternal wound infection, renal failure requiring dialysis, acute respiratory distress syndrome.

Patients' age were in Group I and II (69 \pm 9.3 vs $71 \pm 8.2$ yrs; P > 0.05). Diabetetics in Group I and Group II was $32.4 \%$ vs $29.1 \%$ (P > 0.05). Peripheral vascular disease has been detected in $10.8 \%$ in Group I and $11.6 \%(\mathrm{P}>0.05)$. They were no significant difference when compared to NYHA class in Group I and II.

Concentrations of the $\mathrm{cTn}$-I masses were determined at these time points. The upper limit of normal as defined by our laboratory was $0.04 \mathrm{ng} / \mathrm{ml}$ for cTn-I. ECG criteria for perioperative myocardial infarction were new $\mathrm{Q}$ wave $(0.04 \mathrm{~ms})$ in at least two leads or ECG, ST changes in association with significant c-TnI release.

The mean preoperativel cTn-I value was normal. Immediately after surgery (T1) the mean CTn-I value was $1.09 \pm 0.02 \mathrm{ng} / \mathrm{ml}$ and $1.22 \pm 0.02 \mathrm{ng} / \mathrm{ml}$ in Group 1 and 2, respectively $(\mathrm{P}>0.05)$. cTn-I level was calculated $3.43 \pm 2.60 \mathrm{vs} 1.49 \pm 0.27 \mathrm{ng} / \mathrm{ml}$ in COP and $\mathrm{OPBH}$ group, respectively at postoperative day (POD) $2(\mathrm{P}<0.001, \mathrm{Z}=-5.210)$. POD 3, the mean value of cTn-I was $1.65 \pm 0.32 \mathrm{ng} / \mathrm{ml}$ in Group 1, and $4.40 \pm 5.74$ 
$\mathrm{ng} / \mathrm{ml}$ in Group $2(\mathrm{P}<0.001, \mathrm{Z}=-4.809)$. At the end of 4 . day, $\mathrm{c}-\mathrm{Tn} \mathrm{l}$ levels were $4.30 \pm$ 6.55 in COP group, and $2.69 \pm 1.75 \mathrm{ng} / \mathrm{ml}$ in $\mathrm{OPBH}(\mathrm{P}<0.001, \mathrm{Z}=-4.145)$. In all periods, the level of cTn-I were significantly low in Group I (Table 2) (Figure 1).

Preoperative mean NT-pro BNP concentrations were $289.20 \pm 233.50 \mathrm{pg} / \mathrm{ml}$ and $267.94 \pm 230.20 \mathrm{pg} / \mathrm{ml}$, in Group 1 and 2, respectively $(\mathrm{P}<0.05)$. In Group 1 and 2 , at in the second day, the mean value of NT-Pro BNP was $401.10 \pm 205.20 \mathrm{pg} / \mathrm{ml}$, and $705.11 \pm 405.30 \mathrm{pg} / \mathrm{ml}$, respectively $(\mathrm{P}=0.001)$. in Group 1; POD 2, 3, and 4, NT-Pro BNP values were as follow: $502.17 \pm 344.33,327.26 \pm 383.72$, and $322.30 \pm 370.60 \mathrm{pg} / \mathrm{ml}$, respectively. In Group 2, the mean level of serum NT-pro BNP concentration was $556.20 \pm 463.20 \mathrm{pg} / \mathrm{ml}$ POD 2 after surgery. The level of NT-Pro BNP were as follows: $635.36 \pm 462.61 \mathrm{pg} / \mathrm{ml}$; and $756.97 \pm 502.60 \mathrm{pg} / \mathrm{ml}$. POD 2 (T2), 3 (T3) and 4 (T4). Comparisons of Serum NT-pro BNP concentrations of all sampling times were statistically significant between the groups $(\mathrm{P}=0.001)$ (Table 3 ) (Figure 2).

Preoperative TNF-alpha levels were $2.20 \pm 3.03 \mathrm{pg} / \mathrm{ml}$ and $2.94 \pm 2.97 \mathrm{pg} / \mathrm{ml}$, in Group 1 and 2, respectively $(\mathrm{P}>0.05)$. In Group 1 and 2, at $\mathrm{T}(1)$, the mean value of

Table 2. Preoperative (basal) and postoperative cardiac troponine-I levels in both groups for each time interval.

\begin{tabular}{|c|c|c|c|c|}
\hline & Group 1 & Group 2 & $\mathrm{P}$ & $\mathrm{Z}$ \\
\hline $\mathrm{T}$ (basal) & 0.003 & 0.004 & 0.94 & \\
\hline $\mathrm{T} 1$ & $1.09 \pm 0.02$ & $1.22 \pm 0.02$ & $>0.05$ & \\
\hline $\mathrm{T} 2$ & $1.49 \pm 0.27$ & $3.43 \pm 2.60$ & $<0.001$ & -5.210 \\
\hline $\mathrm{T} 3$ & $1.65 \pm 0.32$ & $4.40 \pm 5.74$ & $<0.001$ & -4.809 \\
\hline $\mathrm{T} 4$ & $2.69 \pm 1.75$ & $4.30 \pm 6.55$ & $<0.001$ & -4.145 \\
\hline
\end{tabular}

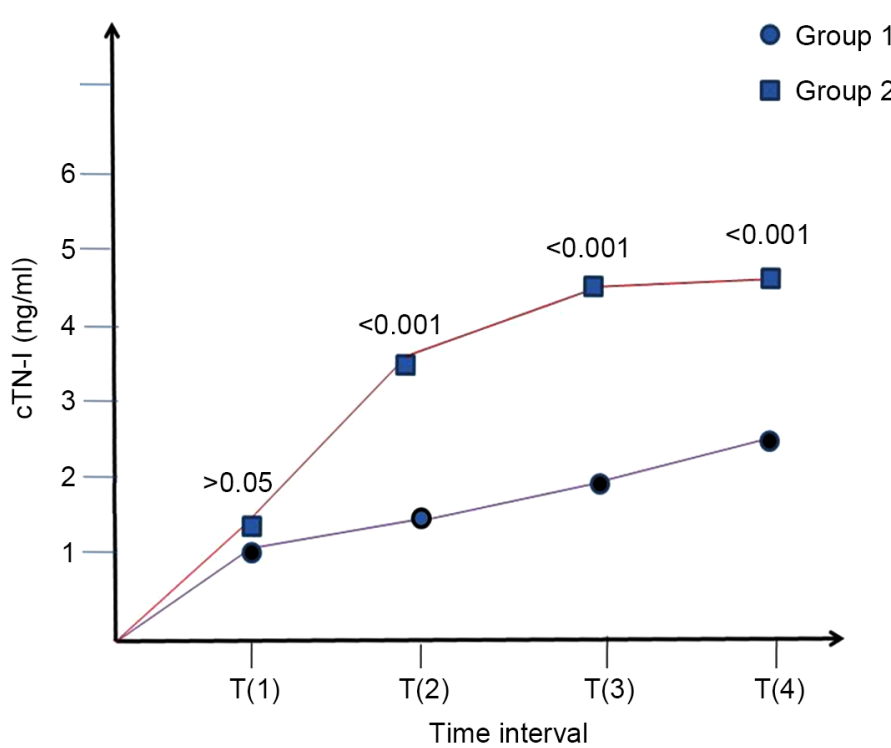

Figure 1. Shows that the changes of cTn-I blood levels including preoperative and postoperative time intervals. 
Table 3. Preoperative (basal) and postoperative Pro-Brain Natriuretic Peptid levels as pg/ml. for each time interval. (Peak serum NT-Pro BNP levels at pre- and postoperative periods).

\begin{tabular}{cccc}
\hline & Group 1 & Group 2 & P \\
\hline T(basal) & $289.20 \pm 233.50$ & $267.94 \pm 230.20$ & $>0.05$ \\
T1 & $401.10 \pm 205.20$ & $705.11 \pm 405.30$ & 0.001 \\
T2 & $502.17 \pm 344.33$ & $556.20 \pm 463.20$ & 0.034 \\
T3 & $327.26 \pm 383.72$ & $635.36 \pm 462.61$ & $<0.001$ \\
T4 & $322.30 \pm 370.60$ & $756.97 \pm 502.60$ & 0.0001 \\
\hline
\end{tabular}

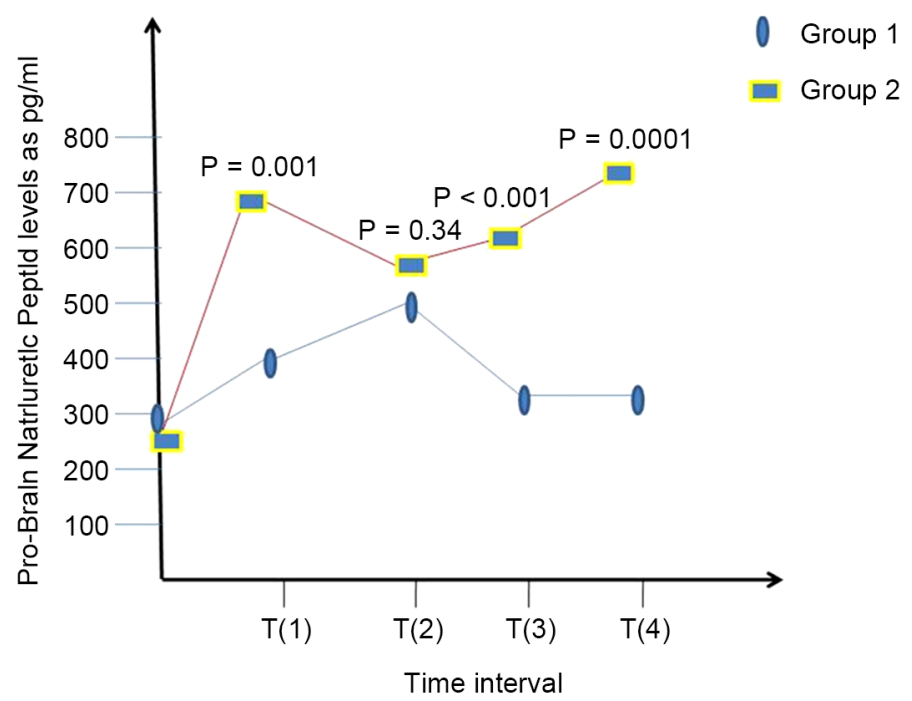

Figure 2. Demonstrates the comparisons of serum NT-pro-brain natriuretic peptid concentrations of all intervals. In all periods NT-pro-brain natriuretic peptid are statistically significant between the groups in the postoperative periods.

TNF-alpha was $19.10 \pm 5.15 \mathrm{pg} / \mathrm{ml}$, and $27.1 \pm 5.3 \mathrm{pg} / \mathrm{ml}$, respectively $(\mathrm{P}=0.001)$. In Group 1; at $\mathrm{T}(2), \mathrm{T}(3)$, and $\mathrm{T}(4)$, TNF-alpha values were as follow: $24.17 \pm 4.3,33.26 \pm$ 8.2 , and $42.37 \pm 13.6 \mathrm{pg} / \mathrm{ml}$, respectively. In the same time, In Group 2, the mean levels of serum TNF-alpha concentrations were $25.11 \pm 4.82 \mathrm{pg} / \mathrm{ml}$ in $\mathrm{T}(1)(\mathrm{P}>0.05)$. The level of TNF-alpha were as follows: $43.16 \pm 14.1 \mathrm{pg} / \mathrm{ml}, 63.16 \pm 11.7 \mathrm{pg} / \mathrm{ml}$, and $60.07 \pm$ $13.55 \mathrm{pg} / \mathrm{ml}$. at 2, 3 and 4. POD. Comparisons of Serum TNF-alpha concentrations of the last three times were statistically significant between the groups (Table 4).

Blood urea nitrogen and serum creatinine levels were measured preoperatively during hospital stay, and postoperative $\mathrm{Cr}$ and BUN within postoperative 1 day were collected. All samples were analyzed immediately after surgery (T1). Also, serum electrolide concentration was measured every $4 \mathrm{~h}$ during the first 24 postoperative hours. Urine output was obtained by urinary catheter during $48 \mathrm{~h}$ postoperatively, and the measurements were made hourly. Urine output during and after CBP, fluid balance and diuretic use were noted. e-GFR was measured from the modification of diet in renal disease equation: eGFR $\left(\mathrm{ml} / \mathrm{min} / 1.73 \mathrm{~m}^{2}\right)=186 \times(\text { Serum Cr mg/dl })^{-1.154} \times(\text { age })^{-0.203}$. 
Repeated creatinine clearance (CCr) was estimated from the standard formula of Cockroft-Gault equation.

$\mathrm{C}_{\mathrm{Cr}}=(140-$ age in years $) \times($ body weight $) /(72 \times \mathrm{SCr}$ in $\mathrm{mg} / \mathrm{dl})$. For females, the obtained result was multiplied by 0.85 .

Percent change in serum creatinine $(\% \mathrm{Cr})$ was calculated by: [(highest postoperative $\mathrm{Cr}) /($ baseline preoperative $\mathrm{Cr})]-1] \times 100 \%$.

The mean creatinine level and eGFR was $1.01 \pm 0.22 \mathrm{mg} / \mathrm{dl}$, and $83.9 \pm 16.9 \mathrm{ml} / \mathrm{min}$. in Group 1. Creatinine clearance was $87.1 \pm 20.7 \mathrm{ml} / \mathrm{min}$. in Group 1. Microalbuminuria has been detected in 13 patients and 17 patients with diabetes in Group I and II, respectively. In both groups, the patients were classified as having mild renal disfunction (eGFR $\leq 60-89 \mathrm{ml} / \mathrm{min} / 1.73 \mathrm{~m}^{2}$ ). Postoperatively, $54 \%$ as having moderate renal dysfunction in Group $1\left(30-59 \mathrm{~mL} / \mathrm{min}\right.$ per $\left.1.73 \mathrm{~m}^{2}\right)$. Urine excretion during CPB and operation were more pronounced in the $\mathrm{OPBH}$ group than in subjects underwent $\mathrm{COP}$ ( $\mathrm{P}=0.002$, and $\mathrm{P}=0.04$, respectively) (Table 5). Fluid intake and urine excretion during the first $24 \mathrm{~h}$ after surgery were significant when compared both groups (2960 \pm $1014 \mathrm{ml}$ vs $1801 \pm 675 ; \mathrm{P}=0.041$ ). Daily furosemide doses and serum potassium levels

Table 4. Basal and postoperative blood tumor necrosis factor-alpha levels as $\mathrm{pg} / \mathrm{ml}$. for each time interval in Group I and II.

\begin{tabular}{cccc}
\hline & Group 1 & Group 2 & P \\
\hline T(basal) & $2.20 \pm 3.03$ & $2.94 \pm 2.97$ & $>0.05$ \\
T1 & $19.10 \pm 5.15$ & $25.11 \pm 4.82$ & $>0.05$ \\
T2 & $24.17 \pm 4.3$ & $43.16 \pm 14.1$ & 0.001 \\
T3 & $33.26 \pm 8.2$ & $63.16 \pm 11.7$ & 0.001 \\
T4 & $42.37 \pm 13.6$ & $60.07 \pm 13.55$ & 0.001 \\
\hline
\end{tabular}

Table 5. Postoperative findings in three study groups.

\begin{tabular}{cccc}
\hline Data variables & Group I & Group II & P \\
\hline post-operative BUN (1st d) & $28.9 \pm 1.35$ & $\mathbf{4 9 . 9} \pm \mathbf{1 . 5 ^ { * }}$ & 0.001 \\
post-operative BUN (2nd d) & $32.1 \pm 1.50$ & $\mathbf{5 2 . 3} \pm \mathbf{3 . 8 ^ { * }}$ & 0.001 \\
post-operative creatinine (1st d) & $1.8 \pm 0.10$ & $\mathbf{2 . 4} \pm \mathbf{0 . 1}$ & 0.001 \\
post-operative creatinine (2nd d) & $1.9 \pm 0.2$ & $\mathbf{2 . 9} \pm \mathbf{0 . 3 ^ { * }}$ & 0.0001 \\
Post-operative hemoglobin & $10.3 \pm 1.30$ & $9.9 \pm 2.0$ & 0.101 \\
1st day post-operative sodium & $135.0 \pm 3.00$ & $\mathbf{1 3 3 . 0 \pm 0 . \mathbf { 8 } ^ { * }}$ & 0.002 \\
Intra-operative urine output & $497.0 \pm 180.00$ & $504.0 \pm 166.0$ & 0.22 \\
Post-operative urine output & $698.0 \pm 223.00$ & $\mathbf{5 6 1 . 0 \pm 1 2 9 . 0 ^ { * }}$ & 0.003 \\
Preoperative glomerular filtration rate & $59.5 \pm 4.30$ & $58.0 \pm 3.8$ & 0.440 \\
Post-operative glomerular filtration rate & $70.6 \pm 3.70$ & $\mathbf{5 9 . 5} \pm \mathbf{4 . 1}$ & 0.001 \\
\hline
\end{tabular}

* Statistical significance. 
did not differ between the two groups. Three patients in Group I (2.7\%), and 6 patients $(6.2 \%)$ in Group II required renal replacement therapy after surgery $(\mathrm{P}<0.001)$. Postoperative mean $\mathrm{Cr}$ and eGFR values are presented in Table 5. Postoperative peak $\mathrm{Cr}$ and \% serum $\mathrm{Cr}$ were significantly higher in Group $2(\mathrm{P}=0.001$, and $\mathrm{P}<0.001$, respectively). Furthermore, the incidence of $\geq 50 \% \mathrm{Cr}$ was significantly higher in Group 2 when compared with Group 1 (48.9\% vs $19.7 \%, \mathrm{P}<0.001)$. Postoperative minimum eGFR were significantly lower in group 2 than they were in the OPBH group ( $\mathrm{P}=$ 0.002). Development of new CCr less than $50 \mathrm{ml} / \mathrm{min}$ postoperatively was significantly higher in group 2 compared with OPBH group ( $24 \%$ vs $58 \%$; $<0.001)$.

\section{Discussion}

Acute renal failure requiring dialysis occurs in $1.5 \%$ of patients who have preoperative normal renal functions following open heart operations. However, AKD develops 16\% $30 \%$ of patients with preoperative impaired renal functions. Preoperative low glomerular filtration rate was one of the main risk factor of $\mathrm{AKD}$ following cardiac surgery. Therefore, this morbid and lethal condition remains a major problem in the cardiac surgery era. Clinical manifestations of postoperative renal failure is in a variety of settings with ranging from a minimal elevation in serum creatinine to anuric renal failure requiring renal replacement therapy. As a result, the implications of renal injury after cardiac surgery are very well-known to cardiac anesthesiologists and intensivists.

Our study results demonstrate that OPBH surgery in patients with preoperative mild renal disease who undergoing CABG surgery is associated with improved renal function compared with conventional on-pump technique. The present study also shows that COP technique is associated with high level of postoperative TNF-alpha and NT-Pro-BNP release which indicates peroperative inflammation. Therefore, our research shows that $\mathrm{OPBH}$ surgery can be more safe and feasible in these particular patients.

Independent risk predictors of postoperative kidney disease after cardiac surgery are age, preoperative renal dysfunction, poor left ventricle, and diabetes [6] [7] [8]. In addition, congestive heart failure [9], urgent operation, prolonged CPB duration [10] [11], low cardiac output [12] peripheral vascular disease [11], chronic obstructive lung disease [12], valvular heart disease, and previous cardiac surgery are another independent risk factors.

Postoperative kidney disease is a strongly independent mortality factor after CABG surgery. Various treatment measures were used in the different trials to protect the kidneys during the perioperative period. Interventions included dopamine and its analogue or agonist (dopexamine or fenoldopam) have been researched in previous studies [12]-[18]. Diuretics (mannitol, furosemide) [19] [20], in previous reports and calcium channel blockers (diltiazem, nicardipine, felodipine, verapamil, nimodipine) have also used to protect renal impairement in previous investigations [21] [22]. ACE inhibitors have been investigated by Colson et al. and Ryckwaert et collegues [23] [24]. N-acetyl cysteine, atrial natriuretic peptide, prostaglandin, theophylline have been used in a 
number of studies [25] [26] [27] [28]. To provide postoperative AKD, off-pump cardiac surgery technique [29] [30] and an extraperitoneal approach to aortic surgery [31] have been researched previously. Studies looked at the effects of hydration fluids [32] [33] [34].

Extracorporeal circulation has several adverse effects on renal functions due to non-pulsatile flow properties [35]. The effect of free hemoglobin released as a result of haemolysis [36]. In fact, afferent arteriolar vasoconstriction has a major impact on the pathophysiology of acute renal insult [36]. Strategies of CPB technique in CABG patients with preoperative renal disease may provide renoprotection after surgery. Many of pharmacologic strategies such as $\mathrm{N}$-achethyl systeine use, dopamine infusion, to avoid ACE inhibitor or diuretic use, have been suggested to increament renal blood flow, and decreased renal vascular resistance. Unfortunately, inhibition of sodium reabsorption and increasing tubular solute flow with diuretics have not been consistently shown to be renoprotective during the cardiac surgical patients [37]. Recently, Bove et collegues used fenoldopam mesylate as a selective dopamine-1 receptor agonist to reduce the risk of acute renal failure after cardiac surgery in high-risk patients compared with dopamine in a prospective randomized trial [38]. However, they showed that the drug use was not appropriate to inhibit renal disfunction in theirs patients. Therefore, we researched the effects of two different techniques on renal outcomes in our patients with moderate renal impairement.

There are no definitive evidence from the available publications demonstrates that during cardiac surgery may protect the renal functions. The criteria used to diagnose acute renal damage varied in many of the previous studies inwhich suffered from unsatisfied methods. Recent methods of detecting renal damage such as the use of specific biomarkers and the best criteria for identifying renal damage [RIFLE (risk, injury, failure, loss of kidney function and end-stage renal failure)] or AKI may have to be explored further to determine any possible benefit derived from interventions used to protect the renal functions during the perioperative period.

\section{Study Limitations}

The present study has some limitations, including non-randomised design and relatively small sample size. However, our population contained propensity-matched, homogeneous patients undergoing surgery using two different techniques. Therefore, other factors interacting with the frequency of postoperative complications due to differences in surgical technique or patient demographics were excluded.

\section{Conclusion}

Our prospective study showed that the renal beneficial effects of OPBH technique in CABG surgery in well-hydrated patients with preoperative impaired renal function. Our clinical practice demonstrated that $\mathrm{OPBH}$ may be considered in these high-risk patients. However, in our opinion, further prospective, randomized studies are required. 


\section{References}

[1] Chertow, G.M., Levy, E.M., Hammermeister, K.E., Grover, F. and Daley, J. (1998) Independent Association between Acute Renal Failure and Mortality Following Cardiac Surgery. American Journal of Medicine, 104, 343-348. http://dx.doi.org/10.1016/S0002-9343(98)00058-8

[2] Ivert, T., Holzmann, M.J. and Sartipy, U. (2014) Survival in Patients with Acute Kidney İnjury Requiring Dialysis after Coronary Artery Bypass Grafting. European Journal CardioThoracic Surgery, 45, 312-317. http://dx.doi.org/10.1093/ejcts/ezt247

[3] Conlon, P.J., Stafford-Smith, M., White, W.D., Newman, M.F., King, S., Winn, M.P. and Landolfo, K. (1999) Acute Renal Failure Following Cardiac Surgery. Nephrology Dialysis Transplantation, 14, 1158-1162. http://dx.doi.org/10.1093/ndt/14.5.1158

[4] Zakeri, R., Freemantle, N., Barnett, V., Lipkin, G.W., Bonser, R.S., Graham, T.R., Rooney, S.J., Wilson, I.C., Cramb, R., Keogh, B.E. and Pagano, D. (2005) Relation between Mild Renal Dysfunction and Outcomes after Coronary Artery Bypass Grafting. Circulation, 112, $1270-1275$.

[5] Garg, A.X., Devereaux, P.J., Yusuf, S., Cuerden, M.S., Parikh, C.R., Coca, S.G., et al. (2014) A CORONARY Investigators. Kidney Function after Off-Pump or On-Pump Coronary Artery Bypass Graft Surgery: A Randomized Clinical Trial. JAMA, 311, 2191-2198. http://dx.doi.org/10.1001/jama.2014.4952

[6] Chertow, G.M., Lazarus, J.M., Christiansen, C.L., Cook, E.F., Hammermeister, K.E. and Grover, F. (1997) Preopertive Renal Risk Stratification. Circulation, 95, 878-884.

http://dx.doi.org/10.1161/01.CIR.95.4.878

[7] Conlon, P.J., Stafford Smith, M., White, W.D., Newman, M.F., King, S., Winn, M.P. and Landolf, K. (1999) Acute Renal Failure Following Cardiac Surgery. Nephrology Dialysis Transplantation, 14, 1158-1162. http://dx.doi.org/10.1093/ndt/14.5.1158

[8] Mangano, C.M., Diamondstone, L.S., Ramsay, J.G., Aggarwal, A., Herskowitz, A. and Mangan, D.T. (1998) Renal Dysfunction after Myocardial Revascularization: Risk Factors, Adverse Outcomes, and Hospital Resource Utilization. The Multicenter Study of Perioperative Ischemia Research Group. Annals of Internal Medicine, 128, 194-203. http://dx.doi.org/10.7326/0003-4819-128-3-199802010-00005

[9] Suen, W.S., Mok, C.K., Chiu, S.W., Cheung, K.L., Lee, W.T., Cheung, D., Das, S.R. and He, G.W. (1998) Risk Factors for Development of Acute Renal Failure (ARF) Requiring Dialysis in Patients Undergoing Cardiac Surgery. Angiology, 49, 789-800.

http://dx.doi.org/10.1177/000331979804900902

[10] Zanardo, G., Michielon, P., Paccagnella, A., Rosi, P., Calo, M. and Salandin, V. (1994) Acute Renal Failure in the Patient Undergoing Cardiac Operation. Prevalence, Mortality rate, and Main Risk Factors. Journal of Thoracic and Cardiovascular Surgery, 107, 14891495.

[11] Brown, J.R., Cochran, R.P., Dacey, L.J., Ross, C.S., Kunzelman, K.S., et al. (2006) Perioperative İncreases in Serum Creatinine Are Predictive of İncreased 90-Day Mortality after Coronary Artery Bypass Graft Surgery. Circulation, 114, 1409-1413. http://dx.doi.org/10.1161/CIRCULATIONAHA.105.000596

[12] Barr, L.F. and Kolodner, K. (2008) N-Acetylcysteine and Fenoldopam Protect the Renal Function of patients with Chronic Renal İnsufficiency Undergoing Cardiac Surgery. Critical Care Medicine, 36, 1427-1435. http://dx.doi.org/10.1097/CCM.0b013e31816f48ba

[13] Cogliati, A.A., Vellutini, R., Nardini, A., Urovi, S., Hamdan, M., Landoni, G., et al. (2007) Fenoldopam İnfusion for Renal Protection in High-Risk Cardiac Surgery Patients: A Ran- 
domized Clinical Study. Journal of Cardiothoracic and Vascular Anesthesia, 21, 847-850. http://dx.doi.org/10.1053/j.jvca.2007.02.022

[14] Dehne, M.G., Klein, T.F., Muhling, J., Sablotzki, A., Osmer, C. and Hempelman, G. (2001) Impairment of Renal Function after Cardiopulmonary Bypass İs Not İnfluenced by Dopamine. Renal Failure, 23, 217-230. http://dx.doi.org/10.1081/JDI-100103493

[15] Dural, O., Ozkara, A., Celebioglu, B., Kanbak, M., Ciliv, G. and Aypar, U. (2000) Comparative Study of Dopamine and Mannitol Effects on Renal Function during Cardiopulmonary Bypass by Using N-Acetyl-Beta-D-Glucosaminidase Assay. Turkish Journal of Medical Sciences, 30, 453-457.

[16] Halpenny, M., Rushe, C., Breen, P., Cunningham, A.J., Boucher-Hayes, D. and Shorten, G.D. (2002) The Effect of Fenoldopam on Renal Function in Patients Undergoing Elective Aortic Surgery. European Journal of Anaesthesiology, 19, 32-39. http://dx.doi.org/10.1097/00003643-200201000-00005

[17] O’Hara, J.F., Thomas, J.R., Hsu, T.H.S., Sprung, J., Cywinski, J.B., Rolin, H.A., et al. (2002) The Effect of Dopamine on Renal Function in Solitary Partial Nephrectomy Surgery. Journal of Urology, 167, 24-28. http://dx.doi.org/10.1016/S0022-5347(05)65374-8

[18] Carcoana, O.V., Mathew, J.P., Davis, E., Byrne, D.W., Hayslett, J.P., Hines, R.L., et al. (2003) Mannitol and Dopamine in Patients Undergoing Cardiopulmonary Bypass: A Randomized Clinical Trial. Anesthesia and Analgesia, 97, 1222-1229. http://dx.doi.org/10.1213/01.ANE.0000086727.42573.A8

[19] Lassnigg, A., Donner, E., Grubhofer, G., Presterl, E., Drubl, W. and Hiesmayr, M. (2000) Lack of Renoprotective Effects of Dopamine and Furosemide During Cardiac Surgery. Journal of the American Society of Nephrology, 11, 97-104.

[20] Shim, J.K., Choi, S.H., Oh, Y.J., Kim, C.S., Yoo, K.J. and Kwak, Y.L. (2007) The Effect of Mannitol on Oxygenation and Creatinine Kinase MB Release in Patients Undergoing Multivessel Off-Pump Coronary Artery Bypass Surgery. The Journal of Thoracic and Cardiovascular Surgery, 133, 704-709. http://dx.doi.org/10.1016/j.jtcvs.2006.10.017

[21] Cho, J.E., Shim, J.K., Chang, J.H., Oh, Y.J., Kil, H.K., Rha, K.H., et al. (2009) Effect of Nicardipine on Renal Function after Robot-Assisted Laparoscopic Radical Prostatectomy. Urology, 73, 1056-1060. http://dx.doi.org/10.1016/j.urology.2008.08.490

[22] Bergman, A.S., Odar-Cederlof, I., Westman, L., Bjellerup, P., Hoglund, P. and Ohqvist, G. (2002) Diltiazem İnfusion for Renal Protection in Cardiac Surgical Patients with Preexisting Renal Dysfunction. Journal of Cardiothoracic and Vascular Anesthesia, 16, 294-299. http://dx.doi.org/10.1053/jcan.2002.124136

[23] Colson, P., Ribstein, J., Mimran, A., Grolleau, D., Chaptal, P.A. and Roquefeuil, B. (1990) Effect of Angiotensin Converting Enzyme İnhibition on Blood Pressure and Renal Function during Open Heart Surgery. Anesthesiology, 72, 23-27. http://dx.doi.org/10.1097/00000542-199001000-00005

[24] Ryckwaert, F., Colson, P., Ribstein, J., Boccara, G. and Guillon, G. (2001) Haemodynamic and Renal Effects of İntravenous Enalapril during Coronary Artery Bypass Graft Surgery in Patients with İschaemic Heart Dysfunction. British Journal of Anaesthesia, 86, 169-175. http://dx.doi.org/10.1093/bja/86.2.169

[25] Morgera, S., Woydt, R., Kern, H., Schmutzler, M., DeJonge, K., Lun, A., et al. (2002) LowDose Prostacyclin Preserves Renal Function in High Risk Patients after Coronary Bypass Surgery. Critical Care Medicine, 30, 107-112. http://dx.doi.org/10.1097/00003246-200201000-00017

[26] Kramer, B.K., Preuner, J., Ebenburger, A., Kaiser, M., Bergner, U., Eilles, C., et al. (2002) Lack of Renoprotective Effect of Theophylline during Aortocoronary Bypass Surgery. 
Nephrology Dialysis Transplantation, 17, 910-915. http://dx.doi.org/10.1093/ndt/17.5.910

[27] Prasad, A., Banakal, S. and Muralidhar, K. (2010) N-acetylcysteine Does Not Prevent Renal Dysfunction after Off-Pump Coronary Artery Bypass Surgery. European Journal of Anaesthesiologyh, 27, 973-977. http://dx.doi.org/10.1097/EJA.0b013e3283383506

[28] Ristikankare, A., Kuitunen, T., Kuitunen, A., Uotila, L., Vento, A., Suojaranta-Ylinen, R., et al. (2006) Lack of Renoprotective Effect of İ.V. N-Acetylcysteine in Patients with Chronic Renal Failure Undergoing Cardiac Surgery. British Journal of Anaesthesia, 97, 611-616. http://dx.doi.org/10.1093/bja/ael224

[29] Ascione, R., Lloyd, C.T., Underwood, M.J., Gomes, W.J. and Angelini, G.D. (1999) On Pump versus off Pump Coronary Revascularization: Evaluation of Renal Function. Annals of Thoracic Surgery, 68, 493-498. http://dx.doi.org/10.1016/S0003-4975(99)00566-4

[30] Tang, A.T., Knott, J., Nanson, J., Hsu, J., Haw, M.P. and Ohri, S.K. (2002) A Prospective Randomized Study to Evaluate the Renoprotective Action of Beating Heart Coronary Surgery in Low Risk Patients. European Journal of Cardio-Thoracic Surgery, 22, 118-123. http://dx.doi.org/10.1016/S1010-7940(02)00220-8

[31] Lau, L.L., Halliday, M.I., Smye, M.G., Lee, B., Hannon, R.J., Gardiner, K.R., et al. (2001) Extraperitoneal Approach Reduces İntestinal and Renal Dysfunction in Elective Abdominal Aortic Aneurysm Repair. International Angiology, 20, 282-287.

[32] Dawidson, I.J., Willms, C.D., Sandor, Z.F., Coorpender, L.L., Reisch, J.S. and Fry, W.J. (1991) Ringer's Lactate with or without 3\% Dextran-60 as Volume Expanders during Abdominal Aortic Surgery. Critical Care Medicine, 19, 36-42. http://dx.doi.org/10.1097/00003246-199101000-00012

[33] Harten, J., Crozier, J.E.M., McCreath, B., Hay, A., McMillan, D.C., McArdle, C.S., et al. (2008) Effect of İntraoperative Fluid Optimization on Renal Function in Patients Undergoing Emergency Abdominal Surgery: A Randomized Controlled Pilot Study. International Journal of Surgery, 6, 197-204. http://dx.doi.org/10.1016/j.ijsu.2008.03.002

[34] Marathias, K.P., Vassili, M., Robola, A., Alivizatos, P.A., Palatianos, M., Geroulanos, S., et al. (2006) Preoperative İntravenous Hydration Confers Renoprotection in Patients with Chronic Kidney Disease Undergoing Cardiac Surgery. Artificial Organs, 30, 615-621. http://dx.doi.org/10.1111/j.1525-1594.2006.00270.x

[35] Stott, R.B., Cameron, J.S., Ogg, C.S. and Bewick, M. (1972) Why the Persistently High Mortality in Acute Renal Failure. Lancet, 2, 75-79. http://dx.doi.org/10.1016/S0140-6736(72)91562-0

[36] Balslov, J.T. and Jorgensen, H.E. (1963) A Survey of 499 Patients with Acute Anuric Renal Insufficiency. Causes, Treatment, Complications and Mortality. American Journal of Medicine, 34, 753-764. http://dx.doi.org/10.1016/0002-9343(63)90084-6

[37] Lassnigg, A., Donner, E., Grubhofer, G., Presterl, E., Druml, W. and Hiesmayr, M. (2000) Lack of Renoprotective Effects of Dopamine and Furosemide during Cardiac Surgery. Journal of the American Society of Nephrology, 11, 97-104.

[38] Bove, T., Landoni, G., Calabro, M.G., Aletti, G., Marino, G., Cerchierini, E., Crescenzi, G. and Zangril, A. (2005) Renoprotective Action of Fenoldopam in High-Risk Patients Undergoing Cardiac Surgery: A Prospective, Double-Blind, Randomized Clinical Trial. Circulation, 111, 3230-3235. http://dx.doi.org/10.1161/CIRCULATIONAHA.104.509141 